\title{
Minat Pustakawan dalam Meningkatkan Kualitas Sumber Daya Manusia Melalui Sertifikasi Uji Kompetensi (Studi di Perpustakaan Perguruan Tinggi Negeri di Propinsi Bengkulu)
}

\author{
Rhoni Rodin* \\ e-mail: bangrodin1@gmail.com
}

\begin{abstract}
The study discusses certification of competence test for professional librarians as efforts to improve the quality of human resources in the library. Method of the study is descriptive analytical. The result of the study showed that librarians at state academic libraries in the Province of Bengkulu had interests in improving their quality through certification of competence test. Fifty percent (50\%) of librarians agreed on the importance of certification to improve quality of library human resources. Yet, some others considered that certification was not yet important because it was just a formality, as a condition for promotion and rank. Their actual purpose for joining certification was to get certification allowance. Since regulation on certification is not yet clear in terms of allowance and enforcement, some librarians were not very enthusiastic in joining certification.
\end{abstract}

Keywords: Interest, Certification, Competence Test, Human Resources, Librarians, Academic Libraries

*) Pustakawan STAIN Curup

A. PENDAHULUAN

1. Latar Belakang

Saat ini bangsa Indonesia sudah memasuki era masyarakat ekonomi ASEAN (MEA). Artinya mau tak mau sumber daya manusia (SDM) Indonesia di segala lini kehidupan harus siap bersaing dengan negara lain, salah satunya persaingan dalam dunia kerja. Sumber daya manusia merupakan salah satu unsur yang penting dalam organisasi. Unsur-unsur organisasi dikenal dengan $6 \mathrm{M}$ yaitu Sumberdaya Manusia (Man), Peralatan (Machine), bahan-bahan (Materials), biaya (Money), metode (Method), dan pasar (Market). Banyak teori manajemen mengatakan bahwa SDM merupakan unsur yang paling penting. Hal ini karena SDM sangat menentukan arah dan kemajuan organisasi. Salah satu jenis SDM yang ada di perpustakaan adalah pustakawan. Oleh karena itu, pustakawan harus ikut andil dan mengambil bagian dalam persaingan dunia kerja.

Berdasarkan Pasal 1, Undang undang Nomor 43 tahun 2007 tentang Perpustakaan, pustakawan adalah seseorang yang memiliki kompetensi yang diperoleh melalui pendidikan dan/atau pelatihan kepustakawanan serta mempunyai tugas dan tanggung jawab untuk melaksanakan pengelolaan dan pelayanan perpustakaan. Selanjutnya pada pasal 29 , ayat (1) menyebutkan bahwa tenaga perpustakaan terdiri atas pustakawan dan tenaga teknis perpustakaan; ditegaskan pada ayat (2) dinyatakan bahwa, pustakawan sebagaimana dimaksud pada ayat (1) harus memenuhi kualifikasi sesuai dengan standar nasional

Pustakawan merupakan jabatan profesi dan sejajar dengan profesi-profesi lain seperti profesi peneliti, guru, dosen, hakim, dokter dan lain-lain. Profesi secara umum diartikan sebagai pekerjaan. Menurut Sulistyo-Basuki (1991) ada beberapa ciri dari suatu profesi seperti (1) adanya sebuah asosiasi atau organisasi keahlian, (2) terdapat pola pendidikan yang jelas, (3) adanya kode etik profesi, (4) berorientasi pada jasa, (5) adanya tingkat kemandirian. Karena pustakawan merupakan suatu profesi, maka seorang pustakawan harus sesuai dengan ciriciri profesi tersebut.

Kompetensi bagi beberapa profesi menjadi persyaratan penting terutama jika profesi ini berhubungan dengan nasib atau hidup orang 
lain yang menjadi objek atau klien dari profesi itu. Misalnya profesi dokter menentukan nasib pasien. Jika dokter salah dalam mendiagnosa penyakit seseorang, maka terapi yang berakibat fatal terhadap pasiennya. Profesi pilot juga mempunyai resiko tinggi karena kemahiran seorang pilot dalam menerbangkan pesawat dapat membawa penumpang sampai tempat tujuan. Profesi-profesi yang mempunyai resiko tinggi sangat diperlukan standar kompetensi. Namun demikian, karena tuntutan mutu, banyak organisasi mulai menerapkan standar kompetensi dalam menerima pegawai baru. Seperti pernyataan LGI(2002):

"More and more organizations are incorporating individual competencies into their hiring and performance management systems.... Competencies offer a framework for organizations to use to focus their limited resources."

"Semakin banyak organisasi yang menggabungkan kompetensi individu dalam perekrutan dan sistem manajemen kinerja mereka.... Kompetensi menawarkan kerangka kerja untuk organisasi agar digunakan untuk memfokuskan sumber daya yang terbatas. "

Masalah kompetensi itu menjadi penting, karena kompetensi menawarkan suatu kerangka kerja organisasi yang efektif dan efisien dalam mendayagunakan sumber-sumber daya yang terbatas. Seseorang yang memiliki kompetensi dalam profesinya akan dapat melaksanakan tugas-tugasnya dengan baik serta efisien, efektif, tepat waktu, dan sesuai dengan sasaran. Secara teoritis keberhasilan satu organisasi ditentukan oleh sumber daya manusia yaitu kualitas, etika, dan kepribadian orang-orang dalam organisasi tersebut. SDM yang berkualitas dan beretika profesi adalah inti keberhasilan organisasi. Begitu juga halnya SDM suatu perpustakaan, keberhasilan suatu perpustakaan salah satunya ditentukan oleh faktor SDM.

Berdasarkan pemaparan di atas, maka sertifikasi uji kompetensi pustakawan merupakan suatu tuntutan yang harus dilakukan seorang pustakawan apabila tidak ingin tersingkir dalam persaingan dunia kerja yang bersifat global saat ini. Seorang pustakawan harus kompeten dalam bidangnya, dan kompetensi tersebut harus diuji, kemudian diberikan sertifikat sebagai pengakuan bahwa seorang pustakawan berkompeten dalam bidangnya.

Aryadi (2015:174) dalam penelitiannya menyimpulkan bahwa kompetensi berpengaruh terhadap kinerja pustakawan dan memiliki nilai positif, artinya semakin tinggi kompetensi yang dimiliki pustakawan maka semakin tinggi pula kinerja pustakawan. Kinerja ini sangat erat kaitannya dengan kualitas sumber daya manusia. Sehingga dengan demikian dapat dipahami bahwa kompetensi akan menentukan kualitas dari suatu profesi.

Trianggoto, dkk (2013:54) dalam penelitiannya menyimpulkan bahwa secara simultan, kompetensi memiliki pengaruh yang signifikan terhadap kinerja tenaga perpustakaan. Pengaruh tersebut menunjukkan bahwa semakin baik kompetensi yang dimiliki oleh tenaga perpustakaan akan memberikan pengaruh yang semakin baik terhadap kinerja tenaga perpustakaan. Faktor keterampilan (skill) memberikan kontribusi pengaruh yang paling besar terhadap kinerja tenaga perpustakaan.

Berdasarkan data dari Lembaga Sertifikasi Profesi (LSP) Pustakawan bahwa hingga akhir tahun 2015, di Propinsi Bengkulu baru 2 (dua) orang pustakawan yang telah mengikuti sertifikasi uji kompetensi, meskipun kegiatan ini telah dimulai sejak tahun 2013. Hal ini merupakan salah satu latar belakang dari penulis ingin menggali mengapa sangat sedikit pustakawan di Propinsi Bengkulu yang berminat untuk mengikuti sertifikasi uji kompetensi, padahal ini sangat positif bagi pustakawan.

Berdasarkan penjelasan di atas, maka penulis tertarik untuk menganalisis bagaimana minat pustakawan khususnya di perpustakaan perguruan tinggi negeri untuk mewujudkan SDM berkualitas melalui sertifikasi uji kompetensi. Hal ini merupakan pemikiran bahwa untuk mewujudkan kualitas seorang pustakawan maka harus dilakukan uji kompetensi terhadap bidang atau kluster yang ditekuninya.

\section{Rumusan Masalah}

Berdasarkan uraian di atas maka yang menjadi fokus pembahasan dalam penulisan artikel ilmiah ini yakni bagaimanakah minat pustakawan di perpustakaan perguruan tinggi negeri di Propinsi Bengkulu dalam 
meningkatkan kualitas melalui sertifikasi uji kompetensi?

\section{Tujuan dan Manfaat}

Tujuan dan manfaat yang diharapkan dari penelitian ini secara akademik adalah sebagai berikut:

1. Bagi ilmu perpustakaan dan informasi, dapat memperkaya khazanah penelitian terutama dalam bidang SDM Perpustakaan.

2. Sebagai bahan rujukan untuk penelitian berikutnya yang berkaitan dengan layanan sumber daya manusia (SDM) Perpustakaan.

3. Memberikan kontribusi terhadap kajian tentang konsep-konsep kualitas SDM Perpustakaan dan sertifikasi uji kompetensi.

Sedangkan secara praktis adalah:

1. Sebagai masukan bagi Perpustakaan Nasional RI, Perpustakaan Daerah, Perpustakaan Perguruan Tinggi Negeri, dan Ikatan Pustakawan Indonesia (IPI).

2. Dapat dijadikan bahan pertimbangan dalam penyusunan program peningkatan kualitas SDM Perpustakaan dan Sertifikasi Uji Kompetensi bagi Pustakawan.

3. Bagi perpustakaan perguruan tinggi negeri di Bengkulu, penelitian tentang minat pustakawan untuk mewujudkan kualitas SDM perpustakaan melalui sertifikasi uji kompetensi ini akan bermanfaat bagi pengembangan mutu dan kualitas SDM perpustakaan.

\section{B. TINJAUAN PUSTAKA}

\section{Pengertian dan Definisi Minat}

Secara umum, pengertian minat adalah perhatian yang mengandung unsur-unsur perasaan. Minat merupakan dorongan atau keinginan dalam diri seseorang pada objek tertentu. Misalnya, minat terhadap pelajaran, olahraga, atau hobi. Minat bersifat pribadi (individual). Artinya, setiap orang memiliki minat berbeda dengan minat orang lain. Minat berkaitan erat dengan motivasi seseorang, sesuatu yang dipelajari, serta dapat berubahubah tergantung pada kebutuhan, pengalaman, dan mode yang sedang trend, bukan bawaan sejak lahir. Faktor yang mempengaruhi munculnya minat seseorang tergantung pada kebutuhan fisik, sosial, emosi, dan pengalaman.
Minat diawali oleh perasaaan senang dan sikap positif.

Minat dalam kamus bahasa Indonesia (2005:130) memiliki makna kecendrungan hati yang tinggi terhadap sesuatu. Secara sederhana, minat (interest) berarti kecendrungan dan kegairahan yang tinggi atau keinginan yang besar terhadap sesuatu. Tohirin (2005:130) menyatakan bahwa minat adalah kecendrungan yang tetap untuk memperhatikan dan mengenang beberapa kegiatan, sedangkan menurut Crow dan Crow dalam Djaali (2007: 121) mengatakan bahwa minat berhubungan dengan daya gerak yang mendorong seseorang untuk menghadapi atau berurusan dengan orang lain, benda, kegiatan, pengalaman, yang dirangsang oleh kegiatan itu sendiri.

Menurut Sabri (1995:84) minat adalah "kecenderungan untuk selalu memperhatikan dan mengingat sesuatu secara terus menerus, minat ini erat kaitannya dengan perasaan senang, karena itu dapat dikatakan minat itu terjadi karena sikap senang kepada sesuatu, orang yang berminat kepada sesuatu berarti ia sikapnya senang kepada sesuatu". Menurut Syah (2001:136) minat adalah "kecenderungan dan kegairahan yang tinggi atau keinginan yang besar terhadap sesuatu".

Menurut Marimba (1980:74) minat adalah "kecenderungan jiwa kepada sesuatu, karena kita merasa ada kepentingan dengan sesuatu itu, pada umumnya disertai dengan perasaan senang akan sesuatu itu". Menurut Shalahuddin (1990:95) minat adalah "perhatian yang mengandung unsur-unsur perasaan". Dengan begitu minat, tambah Mahfudh, sangat menentukan sikap yang menyebabkan seseorang aktif dalam suatu pekerjaan, atau dengan kata lain, minat dapat menjadi sebab dari suatu kegiatan.

Berdasarkan beberapa pengertian tersebut di atas dapat diambil kesimpulan bahwa minat akan timbul apabila mendapatkan rangsangan dari luar. Kecenderungan untuk merasa tertarik pada suatu bidang bersifat menetap dan merasakan perasaan yang senang apabila ia terlibat aktif didalamnya. Perasaan senang ini timbul dari lingkungan atau berasal dari objek yang menarik.

\section{Kompetensi dan Profesionalisme}

Kompetensi atau competency adalah kemampuan untuk melaksanakan suatu tugas/ 
pekerjaan yang didasari atas pengetahuan, keterampilan dan sikap sesuai dengan unjuk kerja yang dipersyaratkan. Sedangkan Mirabile dalam Kismiyati (2004) mendefinisikan kompetensi sebagai pengetahuan dan keterampilan yang dituntut untuk melaksanakan dan/atau untuk menunjang pelaksanaan pekerjaan, yang merupakan dasar bagi penciptaan nilai dalam suatu organisasi Menurut definisi ini, faktor-faktor kompetensi yang sangat penting bagi perseorangan maupun organisasi untuk mencapai keberhasilan, meliputi: pengetahuan teknis, pengkoordinasian pekerjaan, penyelesaian dan pemecahan masalah, komunikasi dan layanan, dan akuntabilitas.

Beberapa definisi tentang kompetensi yang dirumuskan sejumlah ahli menambahkan unsur motivasi, sikap dan nilai kepribadian, serta kepercayaan diri. Kompetensi itu bisa diukur, dan dapat dikembangkan, misalnya melalui pendidikan dan pelatihan. Berdasarkan beberapa definisi tersebut dapat dirumuskan bahwa seseorang yang berkompeten adalah seseorang yang penuh percaya diri karena menguasai pengetahuan dalam bidangnya, memiliki kemampuan dan keterampilan serta motivasi tinggi dalam mengerjakan hal-hal yang terkait dengan bidang itu sesuai dengan tata nilai atau ketentuan yang dipersyaratkan.

Suatu jabatan umumnya sangat terkait dengan masalah profesionalisme. Istilah profesionalisme biasanya dikaitkan dengan penguasaan pengetahuan, keterampilan, dan perilaku dalam mengelola dan melaksanakan pekerjaan/tugas dalam bidang tertentu. Profesionalisme pustakawan tercermin pada kemampuan (pengetahuan, pengalaman, keterampilan) dalam mengelola dan mengembangkan pelaksanaan pekerjaan di bidang kepustakawanan serta kegiatan terkait lainnya secara mandiri. Kualitas hasil pekerjaan inilah yang akan menentukan profesionalisme mereka. Pustakawan profesional dituntut menguasai bidang ilmu kepustakawanan, memiliki keterampilan dalam melaksanakan tugas/pekerjaan kepustakawanan. Selanjutnya melaksanakan tugas/pekerjaannya dengan motivasi yang tinggi yang dilandasi oleh sikap dan kepribadian yang menarik, mencapai kepuasan pemustaka. Dengan demikian, kompetensi dan profesionalisme kepustakawanan itu bagaikan dua sisi dari satu mata uang yang sama.

\section{Sumber Daya Manusia di Perpustakaan}

Sumber daya manusia di perpustakaan menurut Pedoman Perpustakaan Perguruan Tinggi terbitan Direktorat Jenderal Pendidikan Tinggi terdiri dari: Pustakawan, tenaga administrasi dan tenaga kejuruan. Pustakawan (dalam hal ini jabatan fungsional pustakawan) di Indonesia mulai diterapkan sejak tahun 1988 yaitu dengan terbitnya Keputusan Menpan nomor 18/1988. Penerapan jabatan fungsional ini merupakan salah satu upaya pemerintah untuk meningkatkan kesejahteraan pegawai sekaligus untuk menetapkan dan mengukur kompetensi pegawai perpustakaan melalui sistem penilaian pelaksanaan pekerjaan. Jenjang jabatan diukur berdasarkan kompetensi yang dimiliki dan dicerminkan dengan nilai kredit kumulatif yang dicapai oleh pegawai yang bersangkutan. Maka seseorang yang menduduki jabatan tertentu telah memiliki kompetensi untuk jabatan tersebut. Keputusan Menpan ini kemudian disempurnakan mengikuti perkembangan atau dinamika Jabatan Pustakawan, makal lahirlah Peraturan Menpan yang terakhir yaitu Permenpan \& RB nomor 9 tahun 2014 tentang jabatan fungsional pustakawan dan angka kreditnya.

\section{METODE PENELITIAN}

Menurut Mardalis (2008:14), metode penelitian adalah suatu metode ilmiah yang memerlukan sistematika dan prosedur yang harus ditempuh dengan tidak mungkin meninggalkan setiap unsur, komponen yang diperlukan dalam suatu penelitian.

Metode yang digunakan dalam penelitian ini yakni metode penelitian deskriptif analitik. Metode penelitian deskriptif analitik, yaitu penelitian dengan cara memusatkan diri pada masalah yang aktual, mengumpulkan data yang relevan, menjelaskan kemudian menganalisa dan dapat ditarik kesimpulan tentang masalah yang dihadapi (Umar, 1997: 37). Studi ini bermaksud menganalisis dan memetakan minat para pustakawan untuk meningkatkan kualitas melalui sertifikasi uji kompetensi. Kajian ini mendeskripsikan masalah secara rinci, baik data-data kuantitatif maupun uraian kualitatif yang mendalam. Teknik pengambilan sampel menggunakan teknik acak sederhana yaitu teknik pengambilan sampel secara acak tanpa memperhatikan strata yang ada dalam populasi itu. 
Responden penelitian ini yakni pustakawan ahli Perpustakaan Perguruan Tinggi Negeri di Propinsi Bengkulu. Di sini akan dicoba digali lebih lanjut dengan wawancara mendalam (indepth interview) mengenai minat mereka untuk mengikuti sertifikasi uji kompetensi ini.

Pengumpulan data dilakukan dengan kuesioner/angket, wawancara, dan dokumentasi. Dalam penelitian ini, seluruh data yang dikumpulkan kemudian dianalisis secara kualitatif dengan mengedepankan uraian-uraian naratif sehingga hasil penelitian ini bisa menggambarkan fenomena yang diteliti secara lebih lengkap dan komprehensif. Penelitian ini tidak dilakukan uji statistik karena tujuan penelitian memang lebih pada upaya menggali kedalaman data dan memahami secara empatif. Kutipan-kutipan wawancara, sepanjang relevan dan memperjelas permasalahan yang dikemukakan akan ditampilkan dalam pembahasan.

\section{HASIL DAN PEMBAHASAN}

1. Kondisi Pustakawan Perpustakan Perguruan Tinggi Negeri di Propinsi Bengkulu

Di Propinsi Bengkulu terdapat 4 (empat) perguruan tinggi negeri yaitu Universitas Bengkulu (UNIB), Institut Agama Islam Negeri (IAIN) Bengkulu, Sekolah Tinggi Agama Islam Negeri (STAIN) Curup Bengkulu, dan Politeknik Kesehatan Bengkulu. Keempat perguruan tinggi negeri ini mempunyai perpustakaan sebagai penunjang tri dharma perguruan tinggi, dan masing-masing perpustakaan memiliki pustakawan yang mengelola perpustakaan secara profesional. Jumlah pustakawan di Perpustakaan perguruan tinggi tersebut pada tabel 1 .

Tabel 1. Jumlah Pustakawan di Perpustakaan Perguruan Tinggi Negeri di Bengkulu

\begin{tabular}{llc}
\hline No & \multicolumn{1}{c}{$\begin{array}{c}\text { Nama Perguruan Tinggi } \\
\text { Negeri }\end{array}$} & $\begin{array}{c}\text { Jumlah } \\
\text { Pustakawan }\end{array}$ \\
\hline 1 & Universitas Bengkulu (UNIB) & 15 \\
2 & IAIN Bengkulu & 7 \\
3 & STAIN Curup Bengkulu & 6 \\
4 & Politekkes Bengkulu & 2 \\
\hline \multicolumn{2}{c}{ Jumlah } & 30 \\
\hline \multicolumn{2}{c}{ Sumber: Data Primer Diolah 2016 }
\end{tabular}

Berdasarkan tabel 1 menunjukkan bahwa jumlah pustakawan terbanyak terdapat di Perpustakaan UNIB dengan jumlah 15 orang.
Sedangkan yang paling sedikit terdapat di Perpustakaan Poltekkes Bengkulu dengan jumlah 2 orang. Jumlah pustakawan perguruan tinggi negeri di Propinsi Bengkulu seluruhnya berjumlah 30 orang.

Apabila 30 pustakawan tersebut dilihat jenjang jabatannya terbagi menjadi dua yaitu terampil dan ahli. Adapun perbandingan antara pustakawan ahli dan terampil dapat dilihat pada tabel 2 .

Tabel 2. Perbandingan antara Pustakawan Ahli dan Terampil

\begin{tabular}{cccc}
\hline No & Jenjang & $\begin{array}{c}\text { Jumlah } \\
\text { (orang) }\end{array}$ & \% \\
\hline 1 & Ahli & 17 & 56,67 \\
2 & Terampil & 13 & 43,33 \\
\hline & Jumlah & 30 & 100 \\
\hline \multicolumn{4}{r}{}
\end{tabular}

Berdasarkan data pada tabel 2 tersebut menunjukkan bahwa jumlah pustakawan ahli pada perpustakaan perguruan tinggi negeri di Bengkulu berjumlah 17 orang, sedangkan pustakawan terampil berjumlah 13 orang. Maka sesuai peraturan yang yang berlaku saat ini yang boleh mengikuti sertifikasi uji kompetensi untuk sementara ditujukan kepada pustakawan ahli.

Berdasarkan data dan fakta di lapangan bahwa di Propinsi Bengkulu baru 2 (dua) orang yang sudah mengikuti sertifikasi uji kompetensi dan dinyatakan lulus. Kedua orang pustakawan tersebut telah mengikuti sertifikasi uji kompetensi pada tahun 2015. Sehingga dengan demikian, berarti 15 orang pustakawan ahli yang belum mengikuti sertifikasi.

Jumlah pustakawan terampil dan pustakawan ahli di perpustakaan perguruan tinggi negeri di Propinsi Bengkulu adalah sebanyak 30 orang (lihat tabel 1, terdiri dari 13 laki-laki $(43,33 \%)$ dan 17 perempuan $(54,28$ $\%)$.

Tabel 3. Sebaran Pustakawan Perpustakaan Perguruan Tinggi Negeri di Propinsi Bengkulu Menurut Jenis Kelamin

\begin{tabular}{cccc}
\hline No & Jenis Kelamin & $\begin{array}{l}\text { Jumlah } \\
\text { (orang) }\end{array}$ & $\%$ \\
\hline 1 & Laki-laki & 13 & 43,33 \\
2 & Perempuan & 17 & 56,67 \\
\hline & Jumlah & 30 & 100 \\
\hline & & Sumber: Data Primer Diolah 2016
\end{tabular}


Tabel 4. Sebaran Pustakawan Perpustakaan

Perguruan Tinggi Negeri di Propinsi Bengkulu Menurut Jenjang Jabatan

\begin{tabular}{clcc}
\hline No & $\begin{array}{c}\text { Jabatan Fungsional } \\
\text { Pustakawan }\end{array}$ & $\begin{array}{c}\text { Jumlah } \\
\text { (orang) }\end{array}$ & \% \\
\hline 1 & Pustakawan pelaksana & 1 & 3,33 \\
2 & Pustakawan pelaksana & 8 & 26,67 \\
& lanjutan & 4 & 13,33 \\
3 & Pustakawan penyelia & 5 & 16,67 \\
4 & Pustakawan pertama & 9 & 30,00 \\
5 & Pustakawan muda & 3 & 10,00 \\
6 & Pustakawan madya & 0 & 0 \\
7 & Pustakawan utama & 30 & 100 \\
\hline \multicolumn{4}{c}{ Jumlah Sumber: Data Primer Diolah 2016 }
\end{tabular}

Tabel 4 menunjukkan bahwa jumlah pustakawan terampil sebanyak 13 orang atau sebesar 43,33\% yang terdiri dari pustakawan pelaksana $3,33 \%$, pustakawan pelaksana lanjutan 26,67 \% dan pustakawan penyelia $13,33 \%$; dan pustakawan ahli sebanyak 17 orang atau sebesar 56,67 \% yang terdiri dari Pustakawan Pertama sebanyak 16,67 \%, Pustakawan Muda sebanyak 30,00 \%, Pustakawan Madya sebanyak 10,00\%, dan Pustakawan Utama $0 \%$. Berdasarkan data tersebut jumlah pustakawan terbanyak adalah pustakawan muda berjumlah 9 orang.

\section{Standar Pengujian dan Sertifikasi}

Pengujian dan sertifikasi adalah dua hal yang berhubungan sebab akibat. Setelah melakukan kuliah selama satu semester, maka di akhir semester dosen akan memberikan ujian untuk mengetahui seberapa jauh seorang mahasiswa menguasai ilmu yang diajarkan, dan hasilnya berupa transkrip nilai. Jika ujian kita baik, maka kita akan lulus dan memperoleh transkrip dengan nilai yang bagus pula. Namun sebaliknya, apabila ujian kita jelek, maka dosen dapat menyatakan mahasiswa yang bersangkutan tidak lulus.

\section{Pengujian (Assessment)}

Setelah mengetahui kompetensi pustakawan, maka harus dibuat mekanisme pengujian (assesment) untuk menilai apakah seseorang sudah memiliki kompetensi yang disyaratkan, yaitu dengan merujuk kepada standar-standar kompetensi yang telah didefinisikan.

\section{Sertifikasi}

Sertifikat diberikan kepada seseorang yang memenuhi standar-standar yang telah ditentukan sesuai dengan bidang keahlian atau pekerjaannya. Sertifikat ini identik dengan ijazah pada pendidikan formal. Bedanya yakni sertifikat ini lebih mengacu kepada keahlian.

Pustakawan dapat menggunakan standarstandar kompetensi untuk masing-masing keahlian, dan mendapat sertifikat pada bidang keahlian atau profesi tertentu. Seseorang biasanya harus menguasai kompetensi inti dan kompetensi pilihan yang telah disyaratkan.

Kompetensi inti (core competency) adalah kumpulan unit-unit kompetensi yang harus dikuasi semua oleh seseorang yang ingin memperoleh sertifikat pada bidang tertentu. Sedangkan kompetensi pilihan (elective competency) adalah kumpulan unit-unit kompetensi dimana apabila seseorang ingin mendapatkan suatu sertifikat, maka harus menguasai beberapa kompetensi yang ada pada kompetensi pilihan ini. Kompetensi inti dan pilihan ini identik dengan mata kuliah wajib dan mata kuliah pilihan di pendidikan tinggi.

\section{Manfaat Kompetensi bagi Pustakawan Indonesia}

Apabila pustakawan Indonesia ingin bersaing di dalam memperebutkan pasar kerja baik di ASEAN maupun di dunia, mau tidak mau Indonesia harus membuat standar kompetensi bagi pustakawan. Standar kompetensi ini sebaiknya mengacu kepada standar kompetensi pustakawan yang berlaku di negara maju seperti Inggris dan Amerika. Standar tersebut kemudian dijadikan acuan dalam melakukan sertifikasi profesi. Jadi seorang pustakawaan yang memiliki sertifikat profesi sebagai pustakawan pelayanan web/web librarian, dia akan diakui oleh sebagai web librarian di manapun ia bekerja. Dengan demikian maka pasar kerja pustakawan Indonesia akan menjadi lebih luas. Sebaliknya, standar kompetensi pustakawan ini akan menjadi filter untuk tenaga kerja yang akan masuk ke Indonesia. Pustakawan dari negara lain tidak bisa sembarangan masuk dan bekerja di perpustakaan-perpustakaan di Indonesia.

Konsekuensinya yakni pustakawan di Indonesia harus meningkatkan kualitasnya sehingga standar kompetensi yang akan dibuat 
dapat mendekati standar kompetensi yang berlaku di negara maju. Jika tidak, ada dua hal yang akan terjadi sebagai akibat dari diberlakukannya standar kompetensi ini. Pertama, jika nilai-nilai pada standar kompetensi dibuat rendah karena ingin menampung pustakawan agar bisa lolos dalam uji sertifikasi kompetensi mengakibatkan sertifikat kita mungkin tidak diakui di tingkat internasional. Jika ini terjadi maka pustakawan Indonesia sulit masuk ke negara lain, dan sebaliknya pustakawan dari negara lain dengan mudahnya masuk ke Indonesia. Kedua, nilainilai pada standar kompetensi dibuat tinggi. Namun resikonya mungkin banyak pustakawan kita yang tidak bisa lolos dalam uji sertifikasi. Keuntungannya, pustakawan kita bisa "laku" di negara lain, dan pustakawan dari negara lain dapat difilter untuk masuk ke Indonesia.

\section{Minat Pustakawan untuk Meningkatkan Kualitasnya Melalui Sertifikasi Uji Kompetensi}

Berdasarkan hasil survey dan wawancara terhadap pustakawan yang ada di perpustakaan perguruan tinggi negeri di Propinsi Bengkulu pada dasarnya mereka berminat untuk mengikuti sertifikasi uji kompetensi ini. Karena sertifikasi uji kompetensi ini sangat bermanfaat dalam meningkatkan kualitas. Adanya sertifikasi uji kompetensi ini akan diperoleh pemetaan kompetensi masing-masing pustakawan yang ada di Indonesia. Kompetensi ini sangat bermanfaat bagi kualitas dan kinerja bagi seorang pustakawan. Sebagaimana penelitian yang telah dilakukan oleh Aryadi (2015:174)

Berdasarkan hasil penyebaran kuesioner yang telah dilakukan, diketahui bahwa minat pustakawan untuk meningkatkan kualitas SDM melalui sertifikasi uji kompetensi dapat dilihat pada tabel 5 .

Tabel 5

Jawaban Responden tentang Pustakawan Harus Meningkatkan Kualitasnya

\begin{tabular}{|c|c|c|c|}
\hline No & $\begin{array}{c}\text { Jawaban } \\
\text { Responden }\end{array}$ & $\begin{array}{l}\text { Frekuensi } \\
\text { (orang) }\end{array}$ & $\begin{array}{c}\text { Prosentase } \\
(\%)\end{array}$ \\
\hline 1 & Sangat Setuju (SS) & 26 & 86,67 \\
\hline 2 & Setuju (S) & 4 & 13,33 \\
\hline 3 & Tidak Setuju (TS) & 0 & 0 \\
\hline 4 & $\begin{array}{l}\text { Sangat Tidak } \\
\text { Setuju (STS) }\end{array}$ & 0 & 0 \\
\hline & Total & 30 & 100 \\
\hline
\end{tabular}

Berdasarkan tabel 5 di atas, menunjukkan bahwa $86,67 \%$ menjawab sangat setuju bahwa pustakawan harus meningkatkan kualitas pustakawan. Hal ini menunjukkan bahwa pustakawan berminat dan sangat setuju untuk meningkatkan kualitas sumber daya manusia (SDM) perpustakaan.

Tabel 6. Jawaban Responden tentang Pentingnya Mengikuti Sertifikasi Uji Kompetensi

Untuk Meningkatkan Kualitas SDM Perpustakaan

\begin{tabular}{|c|c|c|c|}
\hline No & $\begin{array}{c}\text { Jawaban } \\
\text { Responden }\end{array}$ & $\begin{array}{c}\text { Frekuensi } \\
\text { (orang) }\end{array}$ & $\begin{array}{c}\text { Prosentase } \\
(\%)\end{array}$ \\
\hline 1 & Sangat Setuju (SS) & 15 & 50 \\
\hline 2 & Setuju (S) & 15 & 50 \\
\hline 3 & Tidak Setuju (TS) & 0 & 0 \\
\hline 4 & $\begin{array}{l}\text { Sangat Tidak Setuju } \\
\text { (STS) }\end{array}$ & 0 & 0 \\
\hline & Total & 30 & 100 \\
\hline
\end{tabular}

Berdasarkan tabel 6 di atas, menunjukkan bahwa 50\% menjawab sangat setuju dan 50\% juga setuju bahwa pentingnya mengikuti sertifikasi uji kompetensi untuk meningkatkan kualitas SDM perpustakaan. Hal ini menunjukkan bahwa mereka menaruh perhatian yang besar terhadap sertifikasi uji kompetensi ini. Hasil pengolahan angket tersebut sesuai dengan Aryadi (2015: 174) dan Trianggoto (2013: 54).

Berikut ini hasil wawancara terhadap beberapa pustakawan tentang minat mereka meningkatkan kualitas SDM melalui uji kompetensi dapat dilihat sebagai berikut:

Berdasarkan pendapat seorang pustakawan bahwa sertifikasi belum begitu urgen, sebagaimana diungkapkan Sutriono, pustakawan dari IAIN Bengkulu:

"sertifikasi itu penting tapi baru sebatas untuk keperluan naik pangkat...karena saat ini pustakawan masih menjadi makhluk langka tapi sudah banyak beban...belum jadi kebutuhan utama"

Demikian pendapat dari Sutriono yang menyatakan belum begitu urgen. Karena kalau kita melihat sejarah dimulainya sertifikasi banyak yang berasumsi bahwa ketika pustakawan sudah bersertifikasi maka akan mendapatkan tunjangan sertifikasi seperti yang diperoleh guru dan dosen.

Pendapat berbeda diungkapkan oleh Daryono, pustakawan Universitas Bengkulu, yang mengatakan bahwa: 
"sertifikasi pustakawan hanya seperti formalitas untuk menjaga citra pustakawan,." Lebih lanjut beliau mengatakan "sementara yang dikejar hanya untuk naik pangkat, ...semoga ada peningkatan kualitas layanan."

Sementara itu Nanik, pustakawan dari Unib mengatakan bahwa sertifikasi ini bagus...bisa lebih kompeten berdasarkan bidang masingmasing...cuma masih tumpang tindih pengambilan klusternya."

Demikian beberapa pendapat pustakawan yang ada di propinsi Bengkulu berkaitan dengan sertifikasi uji kompetensi ini. Pada dasarnya semua pustakawan berminat untuk meningkatkan kualitasnya melalui sertifikasi uji kompetensi. Bahkan berdasarkan informasi sudah ada beberapa pustakawan telah mengirimkan berkas untuk mengikuti sertifikasi uji kompetensi.

\section{E. KESIMPULAN}

Berdasarkan analisis dan pembahasan yang dipaparkan di atas, maka dapat disimpulkan bahwa semua pustakawan perpustakaan perguruan tinggi negeri di Propinsi Bengkulu berminat untuk meningkatkan kualitas sumber daya manusia (SDM) perpustakaan dengan atau melalui kegiatan sertifikasi uji kompetensi. Hal ini ditunjukkan dengan hasil kuesioner 50\% pustakawan sangat setuju tentang pentingnya mengikuti sertifikasi uji kompetensi untuk meningkatkan kualitas SDM Perpustakaan. Namun di sisi lain, masih banyak pustakawan yang beranggapan bahwa kegiatan ini belum begitu penting dengan alasan bahwa kegiatan ini hanya formalitas belaka sebagai syarat untuk kenaikan jabatan dan pangkat. Sebenarnya orientasi mereka mengikuti sertifikasi uji kompetensi adalah untuk mendapatkan tunjangan sertifikasi. Tidak adanya tunjangan sertifikasi dan belum jelas dan tegasnya regulasi tentang sertifikasi uji kompetensi ini membuat para pustakawan belum begitu bergairah untuk mengikuti kegiatan ini.

\section{DAFTAR PUSTAKA}

Abd. Rachman Abror, (1993). Psykologi Pendidikan, (Yogyakarta: PT. Tiara Wacana).

Ahmad D. Marimba, (1980). Pengantar Filsafat Pendidikan Islam, (Bandung: PT. Alma'arif).

Bandung Hi-Tech Valley (2003). Blue Book IT Human Resource Development. Bandung: KPP ME dan Material PAU ITB.

Cahyo Trianggoro, dkk. (2013). Pengaruh Faktorfaktor Kompetensi Terhadap Kinerja Tenaga Perpustakaan, dalam Jurnal Kajian Informasi dan Perpustakaan. Bandung: Fakultas Ilmu Komunikasi Universitas Padjadjaran.

Djaali (2007). Psikologi Pendidikan. Jakarta: Bumi Aksara.

Harkrisyati Kamil (2004). Perpustakaan sebagai pusat sumber belajar. Makalah Munas dan Seminar Ilmiah FPPTI, Bandung.

Kismiyati, T (2004). Kompetensi Pustakawan. Makalah disampaikan pada Pelatihan Perpustakaan Perguruan Tinggi, tanggal 28 September 2004 di Cisarua, Bogor

Local Government Institut /LGI. (2002). Core Competencies for Library Systems: Word Processing Document Files. University Place, WA: LGI.

M. Alisuf Sabri, (1995). Psikologi Pendidikan, Jakarta: Pedoman Ilmu Jaya.

Mahfudh Shahuddin, (1990). Pengantar Psikologi Pendidikan, Surabaya: Bina Ilmu.

Muhibbin Syah, (2001). Psikologi Pendidikan dengan pendekatan Baru, Bandung: PT. Remaja Rosdakarya.

........, (2009) Psikologi Belajar. Jakarta: Raja Grafindo Persada

Mardalis. (2008). Metode Penelitian Suatu Pendekatan Proposal. Jakarta: Bumi Aksara.

Saleh, A.R. (2004). Standar Kompetensi Pustakawan dan Masa Depan Pustakawan Indonesia. dalam. Dinamika Perpustakaan IPB menuju Universitas Riset. Bogor: IPB Press.

Sulistyo-Basuki (1991). Pengantar Ilmu Perpustakaan. Jakarta: Gramedia Pustaka Utama

Tohirin, Psikologi Pembelajaran PAI, (Jakarta: Raja Grafindo Persada, 2005) hal. 130.

Utomo, B. S. (2004). Pokok-pokok pikiran pengembangan standar kompetens $i$ kepustakawanan. Bahan diskusi di Perpustakaan Nasional RI (tidak dipublikasi). 